\title{
Serum copper: a marker of disease activity in rheumatoid arthritis
}

\author{
AAR YOUSSEF, B WOOD*. DN BARON \\ From the Royal Free Hospital and School of Medicine, London and *Whittington Hospital, London
}

SUMMARY Serum copper concentrations were measured in patients with rheumatoid arthritis (RA), ankylosing spondylitis (AS), osteoarthritis (OA), and in healthy controls. Median serum copper concentrations were raised significantly in RA and AS, but not in OA. Serum copper in RA correlated significantly with a number of disease activity markers - for example erythrocyte sedimentation rate (ESR), C-reactive protein, haemoglobin concentration, morning stiffness, and grip strength. It also correlated well with the overall disease activity as assessed by a composite index. Raised serum copper was associated with severe RA as manifested by the presence of immunoglobulin $\mathrm{M}$ rheumatoid factor, extra-articular features, weak grip and highly active disease. High serum copper might be related to the development of the pathological lesions observed in RA and not just be a secondary response.

The finding of abnormally high scrum/plasma copper concentration in patients with rheumatoid arthritis (RA) has attracted interest. ${ }^{1-5}$ This interest has been further stimulated by the discovery that copper complexes of anti-inflammatory agents are more potent than the parent compounds. ${ }^{67}$ Furthermore, it has been claimed (though not generally accepted) that the traditional use of copper bracelets by arthritic patients results in improvement. ${ }^{89}$

On the other hand, many workers, ${ }^{10-12}$ but not all., ${ }^{13}$ have shown a correlation of serum copper concentration with disease activity in RA.

The purpose of the present study was to cast further light on the significance of raised serum copper in RA patients, particularly its relation to disease activity. The latter was assessed by a newly developed composite activity index (CAI). ${ }^{1+15}$ Scrum copper was also measured in healthy controls and in patients with either osteoarthritis (OA) or ankylosing spondylitis (AS).

\section{Patients and methods}

PATIENTS

The following were included: 60 patients with classical or definite RA as defined by the criteria of the American Rheumatism Association; ${ }^{16} 19$ patients with OA diagnosed clinically and radiologically; 10 patients with AS diagnosed by the New York criteria; ${ }^{17}$ and 14 apparently healthy subjects used as controls. The composition of the groups is shown in Table 1. Serological tests for immunoglobulin $\mathrm{M}$ rheumatoid factor (IgMRF) were positive in $41 \mathrm{RA}$ patients. RA patients receiving oestrogen-containing oral contraceptives (known to $\vec{\varphi}$ increase serum copper values ${ }^{1819}$ ) or wearing copper $\underset{\omega}{\infty}$ bracelets were excluded. All patients were receiving different forms of antirheumatic therapy.

Assessment of the overall disease activity in the RA patients was performed using a CAI, including both clinical and laboratory markers (Table 2) which were $\stackrel{\odot}{\varnothing}$ combined to form a single score ${ }^{1+15}$ Using the CAI score the 60 RA patients were classified into slightly. moderately, and highly active.

CI.INICAL INVESTIGATIONS

The following were measured according to procedures $\overline{7}$ described in detail elsewhere: ${ }^{1+15}$ duration of morning

Table 1 Composition of patient and control groups

\begin{tabular}{|c|c|c|c|c|}
\hline \multirow[t]{2}{*}{ Group } & \multicolumn{2}{|l|}{ Sex } & \multicolumn{2}{|l|}{ Age (yr) } \\
\hline & Male & Female & Merdian & Range' \\
\hline$\overline{\mathrm{RA}}$ & 20 & 40 & 63 & $37-84$ \\
\hline $\mathrm{OA}$ & 2 & 17 & 62 & $40-81$ \\
\hline AS & 9 & 1 & $52 \cdot 5$ & $32-76$ \\
\hline Controls & 5 & 9 & 58 & $33-76$ \\
\hline
\end{tabular}

Table 2 Relation between serum copper concentration ( $\mu$ mol/l) and each CAI criterion

\begin{tabular}{llll}
\hline $\begin{array}{l}\text { Composite activity } \\
\text { index criteria }\end{array}$ & $\begin{array}{l}\text { Noof } \\
\text { patients }\end{array}$ & $\begin{array}{l}\text { Correlation } \\
\text { coefficient }\end{array}$ & $p$ \\
\hline CRP & 60 & $r=0 \cdot 51$ & $<(0 \cdot 001$ \\
ESR & 60 & $r=0 \cdot 47$ & $<0 \cdot 001$ \\
Hb & 58 & $r=-0.43$ & $<0 \cdot(0) 1$ \\
MS & 60 & $r=0 \cdot 26$ & $<0 \cdot 05$ \\
AJ & 60 & $r=0.06$ & NS \\
Joint pain & 53 & $r=0.13$ & NS \\
\hline
\end{tabular}

$r=$ Pearson's correlation coefficient

$r_{s}=$ Spearman $\$$ rank correlation coefficient 
stiffness (MS) ( $\mathrm{min}$ ), joint pain, articular index (AI), grip strength (GS), the number of tender joints.

\section{LABORATORY INVESTIGATIONS}

The following were measured according to standard laboratory methods: ${ }^{1415}$ IgMRF, C-reactive protein (CRP), immunoglobulin (IgG, IgM, IgA), serum albumin, serum alkaline phosphatase (ALP) serum $\gamma$-glutamyltransferase (GGT), erythrocyte sedimentation rate (ESR), total white blood count (WBC), haemoglobin $(\mathrm{Hb})$, platelet count.

Serum copper was measured by a modification of the method described by Piper and Higgins, ${ }^{20}$ using a double beam atomic absorption spectrophotometer (PerkinElmer model 306. Beaconsfield, Buckinghamshire). Protein free extracts were prepared by diluting serum with one volume of $200 \mathrm{~g} / \mathrm{l}$ trichloroacetic acid, followed by mixing and centrifugation. The supernatants were then aspirated directly into the air-acetylene flame.

STATISTICAL. ANALYSIS

Comparison between groups was performed by MannWhitney U test (two tailed). Correlations were calculated using either Pearson's correlation coefficient $(r)$ or Spearman`s rank correlation coefficient $\left(r_{\mathrm{s}}\right)$.

\section{Results}

COMPARISON BETWEEN SERUM COPPER

CONCENTRATIONS IN PATIENTS WITH RA, OA, AS, AND NORMAL CONTROLS (Fig. 1)

Patients in the RA group had a median serum copper value (26.0 $\mu \mathrm{mol} / \mathrm{l})$ significantly higher than that of the normal control group $(21.8 \mu \mathrm{mol} / \mathrm{l} ; p<0.001)$ and the OA group $(21.6 \mu \mathrm{mol} / \mathrm{l} ; \mathrm{p}<0.001)$, but not different from that of the AS group $(26.4 \mu \mathrm{mol} / 1)$. Mean $\pm \operatorname{SD}(\mu \mathrm{mol} / \mathrm{l})$ : control $21 \cdot 4 \pm 3 \cdot 7$, reference range $14 \cdot 0-21 \cdot 8$; RA $26 \cdot 9$ $\pm 6 \cdot 7$. OA $20 \cdot 9 \pm 2 \cdot 7$; AS $25 \cdot 6 \pm 6 \cdot 4$.

SERUM COPPER IN PATIENTS WITH RA

The serum copper level in 60 RA patients showed no correlation with either the patient's age or the duration of disease. Median serum copper concentrations in male $(24 \cdot 0 \mu \mathrm{mol} / \mathrm{l})$ and female $(26.5 \mu \mathrm{mol} / \mathrm{l})$ patients were not significantly different.

RA patients with IgMRF + ve had a significantly higher median serum copper concentration $(29.5 \mu \mathrm{mol} / \mathrm{l})$ than that of patients with IgMRF-ve $(23.4 \mu \mathrm{mol} / \mathrm{l} ; p<0 \cdot 03)$.

RA patients with extra-articular manifestations had a higher median serum copper $(29 \cdot 0 \mu \mathrm{mol} / \mathrm{l})$ than that of patients without them $(24.4 \mu \mathrm{mol} / \mathrm{l})$. However, the difference was not significant.

RA patients treated with gold, penicillamine or corticosteroids had a median serum copper $(25 \cdot 4 \mu \mathrm{mol} / \mathrm{l})$ not significantly different from that of those treated with non-steroidal anti-inflammatory drugs $(26 \cdot 2 \mu \mathrm{mol} / \mathrm{l})$.

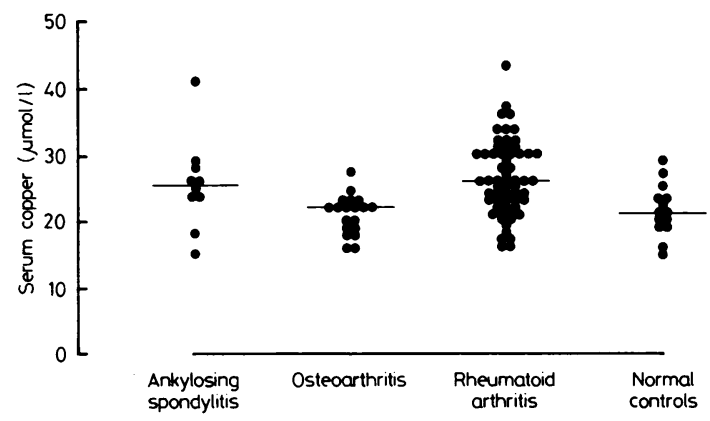

Fig. 1 Serum copper concentrations in different groups of patients and controls. Bars indicate the median.

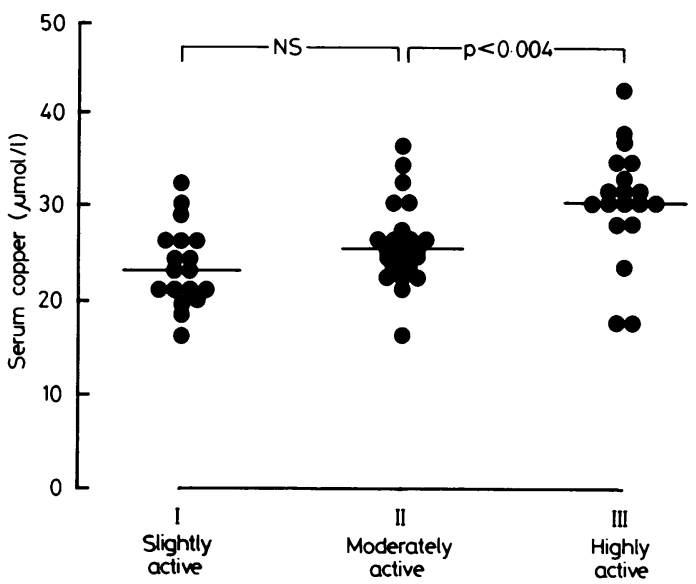

Fig. 2 Serum copper concentrations in different disease activity groups of rheumatoid arthritis. Bars indicate the median.

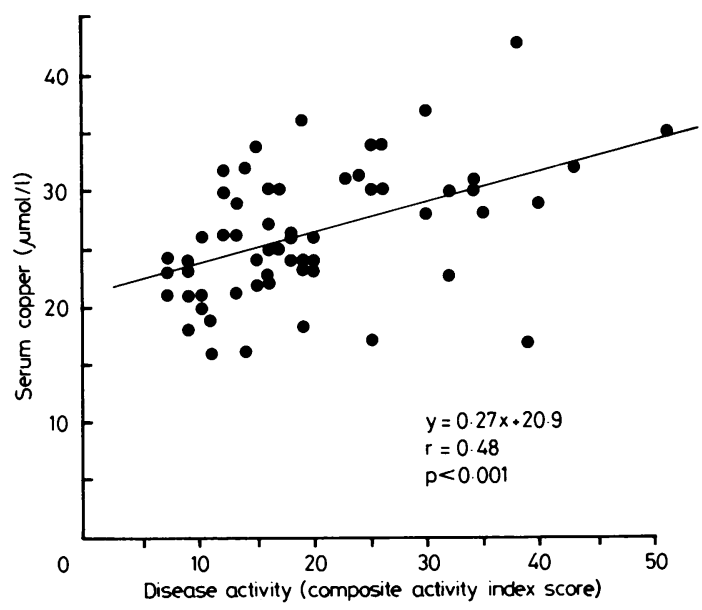

Fig. 3 The relation between serum copper concentration ( $\mu \mathrm{mol} / \mathrm{l})$ and disease activity measured with the composite activity index (CAI) in 60 patients with rheumatoid arthritis. $r=$ Pearson's correlation coefficient. 
The median serum copper concentration of $19 \mathrm{RA}$ patients in the highly active group $(30.5 \mu \mathrm{mol} / \mathrm{l})$ was significantly higher than that of RA patients in both the moderately active and the slightly active groups $(\mathrm{p}<$ 0.004 and $p<0.001$ respectively; Fig. 2).

Highly significant correlation was found between serum copper value and disease activity as measured by the CAI $(r=0.48, \mathrm{p}<0.001 ;$ Fig. 3$)$.

The correlation of serum copper concentration with each individual criterion forming the $\mathrm{CAl}$ is given in Table 2.

The relation between serum copper concentration and other factors believed to be related to disease activity in RA is shown in Table 3.

\section{Discussion}

Our results support the previous reports of raised serum copper both in $\mathrm{RA}^{1-5}$ and in $A S^{11}$ ?1, not related to age, disease duration or drug administration.

Most of the copper is tightly bound to a specific carrier protein caeruloplasmin. This protein is known to behave as an acute phase reactant which increases nonspecifically in response to inflammation. ${ }^{22}$ Caeruloplasmin analysis was not part of the present study. There is ample evidence of its strongly positive correlation with serum copper-for example, Scudder et $a l^{2}$ have reported $r=0.86 \mathrm{p}<0.001$ in normals and $r=0.84 \mathrm{p}<0.001$ in $\mathrm{RA}$. This is supported by other studies in normals ${ }^{21} 2.3$ and in RA. ${ }^{3+} \mathrm{RA}$ is a chronic inflammatory disease with acute exacerbations, and an increase in serum acute phase proteins. Therefore, it is likely that in our RA patients, raised serum copper was a secondary result of high concentrations of caeruloplasmin rather than a primary disturbance of copper metabolism. This explanation is supported by our finding that the acute phase protein CRP and the ESR (which is influenced by the acute phase protein fibrinogen ${ }^{2+}$ ) were raised in RA patients. Both CRP and ESR correlated highly significantly with serum copper values. On the other hand, albumin, which is not an acute phase protein, was not significantly altered, and showed no relation with serum copper. Further evidence

Table 3 Relation between serum copper concentration and other factors related to rheumatoid activity

\begin{tabular}{llll}
\hline Fuctor & $\begin{array}{l}\text { Noof } \\
\text { patients }\end{array}$ & $\begin{array}{l}\text { Correlation } \\
\text { coefficient }\end{array}$ & $p$ \\
\hline 1-GS(mean & 58 & $r=0 \cdot 45$ & $<0 \cdot 001$ \\
of both hands) & & $r=0 \cdot 38$ & $<0 \cdot 004$ \\
2-IgMRF(titre) & 60 & $r=0 \cdot 37$ & $<0 \cdot 05$ \\
3- ALP & 46 & $r=0 \cdot 39$ & NS \\
4- IgG & 23 & $r=0 \cdot 36$ & NS \\
5- IgA & 23 & $r=0 \cdot 27$ & NS \\
6- Platelet count & 48 & $r=0 \cdot 20$ & NS \\
7- Serum albumin & 55 & $r=-0 \cdot 18$ & NS \\
8- IgM & 23 & $r=0 \cdot 13$ & NS \\
9- GGT & 45 & $r=-0 \cdot 09$ & NS \\
10-- WBC & 59 & $r=-0 \cdot 008$ & NS \\
11- Noof & 60 & & \\
tender joints & & &
\end{tabular}

$r=$ Pearson scorrelation coefficient

$r_{1}=$ Spearman is rank correlation coefficient that copper concentrations in RA reflect the acute phase $\frac{0}{\vec{\sigma}}$ response was obtained by our finding that a similar rise in $\frac{}{-}$ serum copper occurs in AS, an inflammatory condition $\overrightarrow{\overrightarrow{\mathrm{F}}}$ also known to be associated with an acute phase response. ${ }^{21}$ Moreover, we did not demonstrate raised copper concentrations in $\mathrm{OA}$, a degenerative condition not associated with an acute phase response.

Based on the above results, a significant correlation $\stackrel{\odot}{\circ}$ was found between serum copper and the overall disease के activity as measured by the CAI which included both $\overrightarrow{0}$ laboratory and clinical markers of disease activity: $\vec{\overrightarrow{ }}$ patients assessed as having highly active disease showed $\vec{\omega}$ significantly higher median serum copper values than patients with either slightly or moderately active disease. ? The lack of correlation between serum copper $\stackrel{\omega}{\omega}$ concentrations and the AI, number of tender joints and pain may reflect the fact that most of our patients were $\vec{A}$ receiving treatment with non-steroidal anti-inflammatory 음 drugs. These drugs improved joint tenderness and pain, but are thought to have little, if any, effect on the acute $c$ phase proteins. ${ }^{25}$ Our results, therefore, suggest that serum copper might provide an additional and useful laboratory marker for the assessment of disease activity in RA.

We have shown that IgMRF was significantly correlated with serum copper and patients with IgMRF+ve exhibited significantly higher serum copper concentrations than those with IgMRF-ve. Moreover, patients with extra-articular manifestations showed a slightly but not significantly higher median serum copper $\stackrel{\mathbb{Q}}{\mathbb{Q}}$ concentration $(29.0 \mu \mathrm{mol} / \mathrm{l})$ than those without $(24.4 \underset{\mathrm{O}}{\overrightarrow{7}}$ $\mu \mathrm{mol} / \mathrm{l})$. The presence of both IgMRF and extra-articular $\frac{3}{3}$ features in RA are known to be associated with severe disease. ${ }^{26}$ Our finding of highly significant inverse correlation between serum copper concentrations and GS might also be considered as further evidence for the association between raised serum copper and severe disease. Weak grip is mainly the result of either highly active disease or a severely deformed hand and both are $O$ manifestations of severe RA.

Oxygen free radicals generated during phagocytosis 을 have been suggested to be responsible for the development $D$ of many pathological lesions in RA. ${ }^{27-30}$ Furthermore, synovial fluid (SF) copper has been recently shown to N correlate significantly with SF free radical oxidation products in patients with RA. ${ }^{31}$ Since copper has been 0 shown in vitro to be a good catalyst for free radical $\omega$ reactions, ${ }^{32}$ the relevance of raised serum copper to the development of such lesions is of interest.

We thank Miss Sue White for the excellent drawings and $\stackrel{\infty}{+}$ Miss Jane Lytle for typing the manuscript. We are grateful 0 to Dr TL Dormandy for advice and criticism. This work formed part of a thesis (AARY) accepted for the degree of $\stackrel{\odot}{\mathcal{Q}}$ $\mathrm{PhD}$ (University of London). AARY was supported by $\mathrm{a} \stackrel{\mathbb{Q}}{\varrho}$ grant from the University of Mansoura, Egypt. 


\section{References}

1 Sorenson JRJ, Di Tommaso D. Significance of plasma copper and caeruloplasmin concentration in rheumatoid arthritis. Ann Rheum Dis 1976;35:317-31.

2 Scudder PR, Al-Timimi D, McMurray W, White AG, Zoob BC, Dormandy TL. Serum copper and related variables in rheumatoid arthritis. Ann Rheum Dis 1978;37:67-70.

${ }^{3}$ Halloran SP. Aspects of copper homeostasis in rheumatoid arthritis and related disorders. University of Surrey: MSc thesis, 1978

${ }^{4}$ Gennan DM, Knudson JML, Dunckley J, MacKinnon MJ, Myers DB, Palmer DG. Serum copper and zinc in rheumatoid arthritis and osteoarthritis. NZ Med J 1980:91:47-50.

5 Granfield LM, Gollan JL. White AG, Dormandy TL. Serum antioxidant activity in normal and abnormal subjects. Ann Clin Biochem 1979;16:299-306.

${ }^{6}$ Sorenson JRJ. Copper chelates as possible active forms of the antiarthritic agents. J Med Chem 1976;19:135-48.

7 Sorenson JRJ, Hangaster W. Treatment of rheumatoid and degenerative diseases with copper complexes. Inflammation 1977;3:217-38.

8 Walker WR, Griffin BJ. The solubility of copper in human sweat. Search (Sydney) 1976:7:100-1.

9 Walker WR, Keats DM. An investigation of the therapeutic value of the 'copper bracelet' - dermal assimilation of copper in arthritic/ rheumatoid conditions. Agents Actions 1976;6:454-9.

${ }^{10}$ Brendstrup P. Serum copper, serum iron and total iron-binding capacity of serum in patients with chronic rheumatoid arthritis. Acta Med Scand 1953;146:348-92.

1 Mäkisara P, Ruutsala HM, Nissilä M, Ruotsi A, Mäkisara GL. Serum copper in rheumatoid arthritis and ankylosing spondylitis. Ann Med Exp Fenn 1968:46:177-8.

12 Brown DH, Buchanen WW, El-Ghobarey AF, Smith WE. Teape J. Serum copper and its relationship to clinical symptoms in rheumatoid arthritis. Ann Rheum Dis 1979:38:174-6.

13 Bajpayee DP. Significance of plasma copper and caeruloplasmin concentrations in rheumatoid arthritis. Ann Rheum Dis 1975:34:162-7.

14 Youssef AAR. Leucocyte superoxide dismutase and serum copper in reumatoid arthritis and other arthritic conditions. University of London: PhD thesis, 1982.

15 Youssef AAR, Richardson AT, Baron DN. A composite index for the assessment of disease activity in rheumatoid arthritis. Rheumatol Rehabil (in preparation).

${ }^{16}$ Roper MW, Bennett GH, Cobb S, Jacox R, Jessar RA. Revision of diagnostic criteria for rheumatoid arthritis. Ann Rheum Dis 1959;18:49-53.

17 Bennett PH, Wood PHN. Population studies of the rheumatic disease. In: Proceedings of the Third International Symposium, June 1966
(Excerpta Medica International Congress Series No 148), Amsterdam, 1966:456.

18 Johnston N, Kheim CT, Kauntz WB. Influence of sex hormones on total serum copper. Proc Soc Exp Biol Med 1959;102:98-9.

19 Evans GW, Cornatzer NF, Cornatzer WE. Mechanism for hormone-induced alterations in serum ceruloplasmin. Am J Physiol 1970;218:613-5.

20 Piper KG, Higgins G. Estimation of trace metals in biological material by atomic absorption spectrophotometry. Proceedings of the Association of Clinical Biochemists 1967;IV:190-7.

${ }^{21}$ Jayson MIV, Davis P, Whicker JT, Walters G. Serum copper and caeruloplasmin in ankylosing spondylitis, systemic sclerosis and morphea. Ann Rheum Dis 1976;35:443-5.

${ }^{22}$ Rice EW. Evaluation of the role of caeruloplasmin as an acute phase reactant. Clin Chim Acta 1961;6:652-5.

${ }^{23}$ Evans GW, Wiederanders RE. Blood copper variation among şpecies. Am J Physiol 1967;213:1183-5.

${ }^{24}$ Hardwicke J, Squire JR. The basis of the erythrocyte sedimentation rate. Clin Sci 1952;2:333-5.

${ }^{25}$ McConkey B, Crockson RA, Crockson AP, Wilkinson AR. The effect of some anti-inflammatory drugs on the acute phase proteins in rheumatoid arthritis. Q J Med 1973;42:785-91.

${ }^{26}$ Mongan ES, Class RM, Jacox RF, Vaughan JH. A study of the relation of seronegative and seropositive rheumatoid arthritis to each other and to necrotizing vasculitis. Am J Med 1969;47:23-35.

27 McCord JM. Free radicals and inflammation: protection of synovial fluid by superoxide dismutase. Science 1974;185:529-31.

28 Puig-Parellada P, Planas JM. Synovial fluid degradation induced by free radicals: In vitro action of several free radical scavengers and anti-inflammatory drugs. Biochem Pharmacol 1977;27:535-7.

${ }^{29}$ Greenwald RA, Moy WW, Lazanus D. Degradation of cartilage proteoglycans and collagen by superoxide radical. Arthritis Rheum 1977:19:799.

${ }^{30}$ Lunec J, Dormandy TL. Fluorescent lipid peroxidation products in synovial fluid. Clin Sci Mol Med 1979;56:53-9.

${ }^{31}$ Lunec J, Halloran SP, White AG, Dormandy TL. Free-radical oxidation (peroxidation) products in serum and synovial fluid in rheumatoid arthritis. J Rheumatol 1981;8:233-45.

${ }^{32}$ Haase SA. Dunkely WL. Ascorbic acid and copper in linoleate oxidation. II. Ascorbic acid and copper as oxidation catalysts. J Lipid Res 1969;10:561-7.

Requests for reprints to: Professor DN Baron, Department of Chemical Pathology, Royal Free Hospital, Pond Street, London, NW3 2QG, England. 